\title{
PENGARUH MODEL VAK (VISUAL, AUDITORI, KINESTETIK) BERBASIS FILM ANIMASI TERHADAP KEMAMPUAN MEMERANKAN CERITA FABEL SISWA SMP
}

\author{
Anise Nudianti, Sumiyadi, Rudi Adi Nugroho \\ Universitas Pendidikan Indonesia \\ Email: anisenudianti@gmail.com,sumiyadi@upi.edu,rudiadinugroho@upi.edu
}

\begin{abstract}
Abstrak: Penelitian ini berpijak adanya permasalahan dalam pembelajaran fabel khususnya seni peran. Penelitian ini mengujicobakan model pembelajaran VAK (Visual, Auditorial, Kinestetik) yang melibatkan tiga unsur gaya dalam pembelajarannya, yaitu penglihatan, pendengaran, dan gerakan. Penerapan model VAK ini dibantu dengan menggunakan media film animasi. Adapun tujuan penelitian ini adalah untuk menguji ada tidaknya perbedaan kemampuan bermain peran cerita fabel antara kelas eksperimen yang menggunakan model VAK melalui film animasi dengan kelas kontrol yang menggunakan model konvensional. Sampel penelitian ini adalah 32 peserta didik kelas VII C sebagai kelas eksperimen dan 32 peserta didik kelas VII D sebagai kelas kontrol di SMP Negeri 12 Bandung. Penelitian ini menggunakan pendekatan eksperimen kuasi dengan desain nonequivalent control group. Rata-rata pretest kelas eksperimen adalah 48, sedangkan kelas kontrol 47. Rata-rata posttest kelas eksperimen adalah 85, sedangkan kelas kontrol 55. Hasil uji hipotesis menunjukkan bahwa Ho ditolak dan Ha diterima. Artinya, terdapat perbedaan signifikan kemampuan memerankan tokoh fabel antara sebelum dan sesudah diterapkannya model VAK melalui film animasi. Dengan demikian, model VAK melalui film animasi efektif diterapkan dalam pembelajaran memerankan fabel.
\end{abstract}

Kata Kunci: model VAK, film animasi, memerankan fabel.

\section{THE EFFECT OF VAK (VISUAL, AUDITORY, KINESTETIC) MODEL ON THE ABILITY TO PLAY THE SCRIPT OF FABEL STORIES OF JUNIOR HIGH SCHOOL STUDENTS}

\begin{abstract}
This research is based on a problem in learning fables, especially acting. This study tested the VAK (Visual, Auditorial, Kinesthetic) learning model which involved three elements of style in learning, namely vision, hearing, and movement. The application of the VAK model is assisted by using animated film media. The purpose of this study was to test whether there was a difference in the ability to play the role of fable stories between the experimental class using the VAK model through animated films and the control class using the conventional model. The sample of this research was 32 students of class VII C as the experimental class and 32 students of class VII D as the control class at SMP Negeri 12 Bandung. This study used a quasi-experimental approach with a nonequivalent control group design. The average pretest of the experimental class was 48, while the control class was 47. The average posttest of the experimental class was 85, while the control class was 55. The results of hypothesis testing showed that Ho was rejected and Ha was accepted. This means that there is a significant difference in the ability to play a fable between before and after the implementation of the VAK model through animated films. Thus, the VAK model through animated films is effectively applied in learning to act out the fable.
\end{abstract}

Keywords: VAK model, animated film, play a fable.

BASASTRA Jurnal Bahasa, Sastra,dan Pengajarannya

Volume 9 Nomor 1, April 2021, P-ISSN 2302-6405, E-ISSN 2714-9765 


\section{PENDAHULUAN}

Moody (Emzir \& Rohman, 2016: 271) mengemukakan bahwa pembelajaran sastra dapat menunjang keterampilan berbahasa, meningkatkan pengetahuan, mengembangkan cipta, rasa, dan karsa, serta mengembangkan pembentukan watak siswa. Berdasarkan kompetensi dasar dalam kurikulum 2013, mampu memerankan isi fabel daerah setempat yang dibaca atau didengar merupakan salah satu tujuan yang harus dicapai oleh peserta didik dalam mata pelajaran Bahasa Indonesia kelas VII SMP. Dengan demikian, dalam hal ini, bermain peran merupakan salah satu kegiatan pembelajaran yang mendukung dalam pelaksanaan kompetensi dasar tersebut.

Salah satu tujuan kegiatan bermain peran dalam pembelajaran sastra adalah untuk mengembangkan karakter positif peserta didik (Handari, 2018). Bermain peran juga merupakan bentuk apresiasi sastra yang memiliki keunikannya sendiri karena melibatkan semua keterampilan berbahasa yaitu menyimak, menulis, membaca, dan berbicara (Sapinhajar, 2016). Bahkan, dalam bermain peran yang identik dengan bermain drama juga melibatkan unsur-unsur kesenian seperti seni tari, seni musik, dan seni rias (Kailani, Murcahyanto, \& Mariadah, 2020). Namun, yang penting lagi menurut Brown (2007: 183-186) dalam bermain peran terdapat unsur bermain dan pemecahan masalah sehingga direkomendasikan untuk diterapkan dalam pembelajaran.

Berdasarkan uraian di atas, dapat dinyatakan bahwa memerankan fabel sama halnya dengan bermain drama, namun dalam memerankan fabel lebih difokuskan ke dalam peniruan tokohtokoh binatang (Nugiyantoro, 2010: 190-191). Pembelajaran memerankan fabel ini sangat bermanfaat bagi peserta didik. Selain isi fabel yang mengandung nilai pendidikan karakter, memerankan fabel juga dapat mengembangkan kemampuan berkomunikasi, melatih kepercayaan diri dalam berbicara, serta melatih daya ingat ingat peserta didik (Zaini, 2008: 136).

Mengingat manfaatnya yang begitu besar bagi pengembangan kompetensi berbahasa dan kompetensi lain bagi peserta didik, KD pembelajaran sastra melalui bermain peran sangatlah penting. Akan tetapi, dari survei awal yang dilakukan Rahmawati \& Suseno (2016) menunjukkan bahwa minat dan motivasi peserta didik untuk bermain peran dikatakan kurang atau rendah. Sehingga bermain peran pun ditampilkan hanya dengan cukup sekadar tampil saja. Hasil penelitian Swadayani, Sutama, \& Gunatama. (2018) juga menunjukkan dalam bermain peran yang ditampilkan peserta didik sering kurang memperhatikan penggunaan warna suara, artikulasi, nada/tekanan, penghayatan, gesture, blocking, dan 
ekspresi yang sesuai dengan karakter tokoh dalam naskah. Selain kurangnya minat dan motivasi, hal yang menyebabkan peserta didik tidak memperhatikan aspek-aspek tersebut adalah adanya kesulitan dan kelemahan yang dialami oleh peserta didik. Kesulitan dan kelemahan itu bisa berupa ketidakpercayaan diri dan kesulitan memerankan tokoh yang sesuai dengan naskah (Rahmawati \& Suseno, 2016).

Kesulitan yang sama dengan kondisi di atas juga terjadi pada siswa kelas VII SMP Negeri 12 Bandung. Dari hasil survei awal diperoleh informasi bahwa faktor penyebab kesulitan memerankan tokoh adalah tiadanya contoh-contoh karakter yang dapat membantu peserta didik untuk mengatur ekspresi, suara, dan gerakan tubuh tokoh yang hendak. Adapun dari hasil wawancara dengan guru diperoleh informasi bahwa selama ini dalam pembelajaran bermain peran dilakukan secara langsung, yaitu peserta didik diberi naskah, kemudian diminta berlatih, dan akhirnya mereka tampil di depan kelas. Hal itu menunjukkan tidak adanya media yang memuat modelmodel ekspresi yang dapat dicontoh siswa. Padahal, media seperti itu penting dihadirkan di kelas. Oleh karenanya, di kelas VII SMP Negeri 12 Bandung perlu diadakan media dalam pembelajaran bermain peran cerita fabel.

Berkenaan dengan pengadaan media pembelajaran tentu perlu diperhatikan jenisnya. Media pembelajaran tidak dapat dioptimalkan hanya dengan menyampaikan pada satu rangsangan (audio, video, atau kinestetik) karena otak manusia memiliki kapasitas yang terbatas untuk memproses informasi hanya dengan menggunakan satu rangsangan saja, yaitu (audio, video, atau kinestetik (Reiner \& William, 2010). Dengan demikian, pembelajaran yang melibatkan media dengan mengaktifkan lebih banyak indra, yaitu mencakup video-audio-kinestetik (VAK) disebut sebagai model VAK. Adapun medianya biasa diistilahkan sebagai media multimoda. Media ini dipandang lebih baik daripada yang hanya satu moda.

Salah satu metode yang dapat dimanfaatkan guru untuk meningkatkan kemampuan berbahasa siswa khususnya menulis yaitu model pembelajaran VAK. Wulansari (2016) menekankan bahwa model pembelajaran VAK merupakan model pembelajaran multisensori yang melibatkan tiga gaya belajar. Rambe \& Zainuddin (2014) menyatakan bahwa VAK merupakan pendekatan dan pengembangan pembelajaran kuantum yang menggabungkan motivasi, keterikatan, dan kebiasaan proses kognitif siswa yang kemudian memengaruhi penggunaan keterampilan metakognitif seperti analisis situasi, self-pacing, dan evaluasi diri untuk menghasilkan hasil belajar yang sesuai dengan ciri khas gaya belajar siswa. 
Hal tersebut dapat dikaitkan dengan berbagai hasil penelitian tentang media pembelajaran telah menemukan bahwa media pembelajaran yang mengintegrasikan jenis-jenis stimulus (misalnya audio dan visual), memberikan manfaat yang lebih signifikan bagi dibandingkan dengan stimulus dari satu modal (Gunawardena, 1995). Sweller (2005) mengemukakan bahwa stimulus multimoda, disajikan dalam proporsi yang tepat, dapat meringankan beban memori kerja selama pemrosesan informasi. Untuk alasan ini, siswa dapat mengoptimalkan pembelajaran mereka karena otak mereka akan dapat memproses lebih banyak informasi.

Ide utama di balik pembelajaran multimedia paling baik digambarkan oleh Mayer (2005) yang merekomendasikan bahwa peserta didik lebih diuntungkan ketika belajar menggunakan kata-kata dan gambar daripada kata-kata saja. Dalam konteks ini, ia lebih lanjut menjelaskan bahwa kata dapat berupa teks tertulis dan lisan, dan gambar dapat berupa gambar, grafik, dan gambar bergerak. Dengan demikian, salah satu media yang memungkinkan untuk mengimplementasikan pembelajaran model VAK adalah pengadaan film animasi.

Di Indonesia telah banyak diadakan penelitian yang bertujuan meningkatkan kompetensi bermain peran cerita fabel dalam pembelajaran sastra di SMP. Swadayani, Sutama, \& Gunatama (2018) telah meneliti kompetensi dasar tersebut melalui pendekatan tindakan kelas. Rukmana (2019) melakukan penelitian melalui eksperimen dengan mengunakan perlakukan berupa pemanfaatan topeng. Adapun penelitian ini juga mengunakan pendekatan penelitian eksperimen, namun perlakuannya berupa penggunaan model VAK berbasis film animasi. Dengan demikian, pemanfaatan model VAK dan film animasi merupakan kebaruan penelitian ini dibandingkan penelitian sejenis. Berdasarkan hal tersebut yang membuat peneliti melakukan penelitian dengan judul "Penerapan Model VAK (Visual, Auditori, Kinestetik) Melalui Film Animasi dalam Pembelajaran Memerankan Fabel pada Siswa Kelas VII SMP Negeri 12 Bandung”.

\section{METODE}

Metode penelitian yang digunakan dalam penelitian ini adalah metode kuantitatif dengan jenis penelitian eksperimen semu atau bisa disebut juga dengan metode eksperimen kuasi (quasi experiment research). Yang menjadi subjek penelitian ini adalah semua siswa kelas VII SMP Negeri Bandung. Akan tetapi, untuk pelaksanaan eksperimen dipilih kelas VII C sebagai kelas eksperimen dan kelas VII D sebagai kelas kontrol

Desain penelitian yang digunakan dalam penelitian ini adalah Nonequivalent Control Group Design. Setyosari (2012: 178) menyatakan bahwa rancangan ini disebut juga dengan untreated control group design with pretest-and posttest. Rancangan 
ini tidak menggunakan random assignment. Artinya rancangan ini tidak melakukan random terhadap kelompok subjek. Hal ini ditunjukkan dengan pemberian garis putus-putus di antara dua kelompok. Dalam desain ini terdapat dua kelompok yang akan diteliti atau diuji. Kelompok pertama yang akan diuji adalah kelompok eksperimen. Sedangkan kelompok yang kedua adalah kelompok kontrol sebagai pembanding. Pada kelompok eksperimen akan diuji dengan menggunakan model VAK melalui film animasi. Desain penelitian dapat dilihat pada tabel berikut ini.

\begin{tabular}{|cccc|}
\hline $\mathrm{E}$ & $\mathrm{O}_{1}$ & $\mathrm{X}$ & $\mathrm{O}_{2}$ \\
$\mathrm{~K}$ & $\mathrm{O}_{3}$ & - & $\mathrm{O}_{4}$ \\
\hline
\end{tabular}

(Setyosari, 2012: 178)

Keterangan:

E :kelas eksperimen

$\mathrm{K}$ :kelas kontrol

$\mathrm{O}_{1} \quad$ :tes awal kelas eksperimen

$\mathrm{O}_{2} \quad$ :tes akhir kelas eksperimen

$\mathrm{O}_{3} \quad$ :tes awal kelas kontrol

$\mathrm{O}_{4} \quad$ :tes akhir kelas kontrol

X :perlakuan pembelajaran di kelas eksperimen dengan menggunakan model VAK melalui film animasi

Pengumpulan data dilakukan dengan teknik tes unjuk kerja menggunakan instrumen lembar observasi untuk menilai kompetensi bermain peran cerita fabel. Aspek yang dinilai meliputi aspek komunikasi suara, komunikasi tubuh, dan penghayatan peran.

\section{HASIL DAN PEMBAHASAN}

Penelitian ini mengujicobakan model VAK (Visual, Auditori, Kinestetik) melalui film animasi dalam pembelajaran memerankan fabel peserta didik kelas VII SMP. Penelitian ini dilaksanakan di SMP Negeri 12 Bandung. Terdapat dua kelas yang digunakan dalam penelitian ini yaitu kelas VII C sebagai kelas eksperimen dan kelas VII D sebagai kelas kontrol.

Terdapat tiga kali pertemuan yang dilaksanakan dalam penelitian ini. Pertemuan pertama digunakan untuk melaksanakan pretest, pertemuan kedua digunakan untuk memberikan perlakuan, dan pertemuan ketiga digunakan untuk melaksanakan posttest. Perlakuan berbeda diberikan kepada kelas eksperimen dan kelas kontrol. Kelas eksperimen diberikan perlakuan dengan menerapkan model VAK melalui film animasi, sedangkan kelas kontrol diberi perlakuan dengan menerapkan model konvensional.

Hasil penilaian pretest dan posttest memerankan fabel peserta didik dinilai oleh tiga orang penimbang. Hasil data tersebut kemudian diolah menggunakan aplikasi SPSS versi 23 dengan melakukan uji reliabilitas, uji normalitas, uji homogenitas, dan uji hipotesis.

Nilai rata-rata pretest yang diperoleh oleh kelas eksperimen yaitu sebesar 48, sedangkan kelas kontrol 
memperoleh nilai sebesar 47. Hasil tersebut menunjukkan bahwa kedua kelas mempunyai kemampuan yang sama dalam pembelajaran memerankan fabel.

Pada saat melaksanakan pretest baik di kelas eksperimen maupun di kelas kontrol, banyak peserta didik yang mengalami kesulitan dalam bermain peran. Kekurangan tersebut terletak pada aspek komunikasi suara, komunikasi tubuh, dan penghayatan peran. Hal tersebut dapat dibuktikan dengan banyaknya jumlah peserta didik yang ada dalam kategori sangat kurang yang disajikan pada Gambar 1. Di kelas eksperimen terdapat 24 orang dalam kategori sangat kurang, 7 orang dalam kategori kurang, dan 1 orang dalam kategori cukup, sedangkan di kelas kontrol terdapat 22 orang dalam kategori sangat kurang, 9 orang dalam kategori kurang, dan 1 orang dalam kategori cukup.

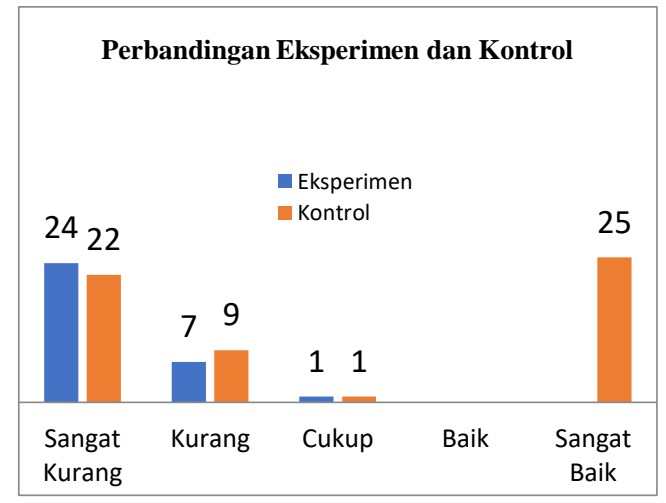

Gambar 1. Distribusi Nilai Pretes

Pada komunikasi suara, peserta didik mengalami kesulitan dalam aspek warna suara. Hal tersebut ditunjukkan dengan kurang mampunya peserta didik dalam menyesuaikan warna suara dengan emosi dan karakter tokoh. Contohnya pada tokoh Singa, warna suara yang dihasilkan seharusnya suara yang besar, tegas, berat, dan menggelegar. Namun, sebagian besar peserta didik masih menyampaikan dengan suara yang datar dan lemah lembut sehingga tidak mencerminkan tokoh Singa.

Selain warna suara, peserta didik juga mengalami kesulitan dalam aspek tekanan. Sebagian besar peserta didik masih banyak yang tidak mampu dalam menyesuaikan tekanan dinamik, nada, dan tempo dengan baik. Misalnya ketika tokoh sedang dalam keadaan marah, maka dialog seharusnya disampaikan dengan nada tinggi tetapi peserta didik menyampaikan dialog tersebut dengan nada rendah. Sehingga terjadi ketidaksesuaian tekanan dengan emosi tokoh.

Pada komunikasi tubuh, peserta didik mengalami kesulitan dalam aspek ekspresi wajah. Peserta didik kurang mampu dalam menyesuaikan ekspresi wajah yang sesuai dengan karakter dan emosi tokoh yang diperankan. Selain aspek ekspresi wajah, peserta didik juga kurang mampu dalam aspek blocking dan gestur. Sebagian peserta didik masih banyak terpaku di satu tempat bahkan sering kali membelakangi penonton. Sehingga kurang mampu dalam memanfaatkan dan menyesuaikan ruang panggung. Hal tersebut disebabkan kurangnya persiapan peserta didik sehingga selalu terpaku pada teks fabel yang dibawa. 
Adapun pada penghayatan peran, peserta didik mengalami kesulitan dalam aspek improvisasi dan konsentrasi. Masih banyak peserta didik yang kurang serius bahkan ada beberapa peserta didik yang bercanda saat proses pembelajaran bermain peran dilaksanakan.

Selain itu, kurangnya keseriusan peserta didik juga berdampak pada penguasaan terhadap cerita. Peserta didik sering kali lupa terhadap dialog dan adegan yang hendak diperankan. Kurangnya kemampuan improvisasi mengakibatkan peserta didik sering kali mengatakan kata "lupa" atau berhenti sejenak untuk mengingat kembali adegan atau dialog tersebut.

Pada saat posttest, kelas eksperimen banyak mengalami peningkatan. Kelas eksperimen mengalami peningkatan yang tinggi pada komunikasi suara, komunikasi tubuh, dan penghayatan peran terutama pada aspek warna/karakter suara, ekspresi wajah, gestur, blocking, dan konsentrasi. Sedangkan kelas kontrol mengalami peningkatan di antaranya pada aspek artikulasi, tekanan, dan blocking.

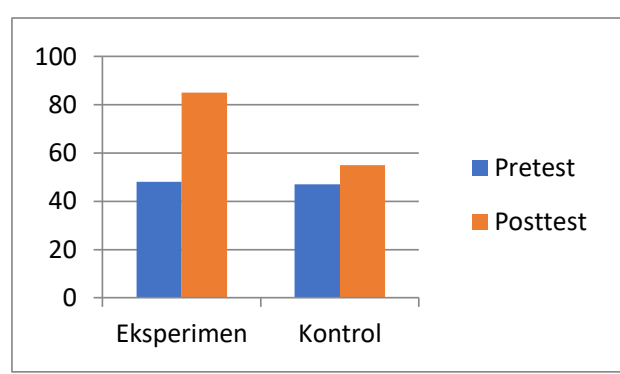

Gambar 2. Rata-rata Nilai Pretes dan Postes
Berdasarkan hasil tersebut menunjukkan bahwa kedua kelas mengalami peningkatan kemampuan dalam pembelajaran memerankan fabel. Akan tetapi, hasil dari kedua kelas tersebut memiliki perbedaan yang signifikan. Datanya dapat dibaca pada Gambar 2.

Pada saat pretest, kelas eksperimen memiliki nilai rata-rata 48 dan kelas kontrol memiliki nilai ratarata yang tak jauh berbeda yaitu 47 . Kemudian setelah diberikan perlakuan dengan menerapkan model VAK melalui film animasi pada kelas eksperimen, nilai posttest yang dihasilkan jauh berbeda. Kelas eksperimen mendapatkan nilai rata-rata sebesar 85 dengan kategori sangat baik sedangkan kelas kontrol mendapatkan nilai sebesar 55 dengan kategori kurang. Perbedaan tersebut juga dapat dilihat dari hasil N-Gain yang diperoleh kelas eksperimen dan kelas kontrol pada saat melakukan pretest dan posttest. Kelas eksperimen memperoleh nilai rata-rata 0,7 dengan kategori tinggi sedangkan kelas kontrol memperoleh nilai rata-rata 0,2 dengan kategori rendah.

Perbedaan peningkatan antara kelas eksperimen dan juga kelas kontrol juga dapat dibuktikan melalui banyaknya siswa kelas eksperimen yang termasuk ke dalam kategori sangat baik, sedangkan peserta didik kelas kontrol masih banyak yang termasuk ke dalam kategori kurang. Hasil tersebut ditunjukkan dengan kelas eksperimen yang memiliki 
sebanyak 25 orang siswa dalam kategori saangat baik dan 7 orang, peserta didik dalam kategori baik, sedangkan kelas kontrol memiliki sebanyak 7 orang peserta didik dalam kategori cukup, 19 orang peserta didik dalam kategori kurang, dan 6 orang peserta didik dalam kategori sangat kurang. Datanya dapat dibaca pada Gambar 3.

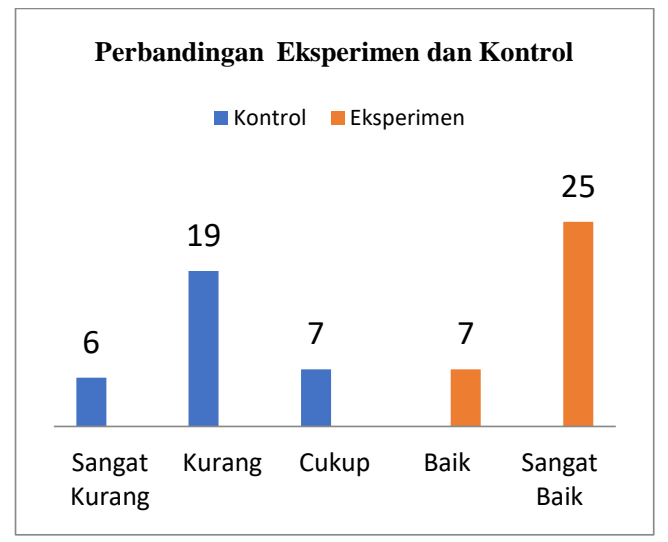

Gambar 3. Nilai Postes

Banyak siswa di kelas kontrol yang masih belum mengerti dan memahami bagaimana teknik dalam bermain peran. Peserta didik masih banyak mengalami kesulitan dalam menyesuaikan warna suara dan ekspresi wajah yang sesuai dengan emosi dan karakter tokoh. Oleh karena itu, nilai posttest peserta didik di kelas kontrol masih banyak berada pada kategori kurang.

Setelah dilakukan uji hipotesis, diperoleh nilai signifikasi yang didapatkan sebesar $0,000<0,05$. Hasil tersebut menunjukkan bahwa $\mathrm{Ha}$ diterima dan Ho ditolak. Sehingga dapat disimpulkan bahwa terdapat perbedaan antara kemampuan memerankan fabel kelas eksperimen yang menerapkan model VAK melalui film animasi dengan kelas kontrol yang tidak menerapkan model VAK melalui film animasi.

Berdasarkan hasil analisis di atas menunjukkan bahwa pembelajaran yang menggunakan model VAK (Visual, Auditori, Kinestetik) melalui film animasi efektif dan memberikan perubahan yang baik pada kemampuan memerankan fabel peserta didik. Temuan ini sejalan dengan hasil penelitian Suaib (2017) yang menemukan bahwa model VAK dapat meningkatkan penguasaan kosa kata siswa. Adapun hasil penelitian yang dilakukan melalui eksperimen oleh Ramadian, Cahyono, \& Suryati (2019) yang menunjukkan bahwa model VAK efektif meningkatkan kemampuan menulis siswa. Demikian halnya dengan temuan Rambe dan Zainudin (2014) yang mendapati model VAK meningkatkan kompetensi menulis.

Secara rinci hasil penelitian ini mendapati bahwa pada awalnya, kemampuan siswa di kelas eksperimen dalam pembelajaran memerankan fabel pada saat pretest dinilai sangat kurang. Peserta didik menunjukkan bahwa mereka mengalami kesulitan dalam memahami teknik dalam bermain peran. Hal tersebut dapat dibuktikan pada saat pretest, peserta didik kurang mampu dalam menjiwai dan menghayati peran sesuai dengan tokoh yang terdapat dalam naskah.

Peserta didik kurang memahami bagaimana cara untuk memperhatikan komunikasi suara, komunikasi tubuh, 
dan penghayatan peran agar sesuai dengan tokoh yang diperankan. Sebagian besar peserta didik masih banyak kesulitan dalam menghasilkan karakter/warna suara, ekspresi wajah, dan emosi yang sesuai dengan tokoh yang diperankan. Selain itu, peserta didik juga masih banyak yang belum mampu untuk memanfaatkan dan menguasai ruang dengan baik, bahkan lebih buruknya lagi masih banyak peserta didik yang sering membelakangi penonton. Oleh karena itu, nilai rata-rata yang diperoleh kelas eksperimen pada saat pretest yaitu 48 .

Berdasarkan nilai rata-rata tersebut, kemampuan memerankan fabel peserta didik kelas eksperimen masing kurang atau rendah. Setelah diberi perlakuan yaitu penerapan model VAK melalui film animasi, terdapat peningkatan kemampuan memerankan fabel peserta didik kelas eksperimen. Pada saat posttest, peserta didik sudah dapat memerankan fabel dengan memperhatikan komunikasi suara, tubuh, dan penghayatan peran yang sesuai dengan tokoh yang terdapat dalam naskah, sehingga nilai rata-rata yang diperoleh pada saat posttest jauh meningkat yaitu 85 .

Kemampuan awal peserta didik dalam memerankan fabel di kelas kontrol sebelum diberi perlakuan dinilai sangat kurang atau rendah. Hal tersebut sama halnya dengan kemampuan awal kelas eksperimen, yang mana masih banyak kekurangan dan kesulitan yang dialami oleh peserta didik terutama pada aspek warna suara, ekspresi wajah, blocking, dan emosi, sehingga pada saat pretest kelas kontrol memperoleh nilai rata-rata sebesar 47 .

Pada saat pemberian perlakuan, kelas kontrol tidak diberi penerapan model VAK melalui film animasi melainkan diterapkan model konvensional. Namun, pada saat posttest peserta didik kelas kontrol hanya mengalami sedikit peningkatan dalam kemampuan memerankan fabel yang artinya hanya sedikit mengalami perubahan. Sehingga nilai rata-rata yang diperoleh adalah sebesar 55 yang berarti kemampuan dalam memerankan fabel masih dinilai kurang atau rendah.

Keefektifan penerapan model VAK dalam pembelajaran bermain peran cerita fabel pada siswa SMP ini sejalan dengan hasil penelitian Swadayani, Sutama, \& Gunatama (2018). Peneliti tersebut menyimpulkan bahwa model VAK dapat meningkatkan motivasi dan keterampilan bermain peran siswa SMP di Singaraja. Penelitian dilakukan melalui pendekatan penelitian tindakan kelas. Adapun penelitian ini dilakukan dengan pendekatan eksperimen.

Penelitian ini juga sejalan dengan temuan Joma, Al-Abed \& Nafi. (2016) serta Swadayani, Sutama, \& Gunatama (2018) berkaitan dengan keefektifan bermain peran dalam pembelajaran. Hal itu ditunjukkan adanya peningkatan motivasi belajar baik pada 
kelompok eksperimen maupun kelompok kontrol yang mana keduanya dilakukan secara kolaboratif bersama teman untuk bermain peran. Joma, AlAbed \& Nafi (2016) menjelaskan bahwa adanya kerja secara kooperatif dan kolaboratif membuat siswa mengikuti pembelajaran, namun serasa bermain.

Adanya perubahan positif siswa dalam bermain peran di kelas eksperiman terutama pada aspek warna suara, ekspresi wajah, blocking, dan emosi tersebut setelah mereka menyimak penayangan film animasi tentang binatang. Mereka selanjutnya diminta berlatih menirukan ekspresi tokoh-tokoh binatang yang telah dilihatnya serta didengar suaranya. Dengan demikian, dalam pembelajaran dilibatkan keaktifan indra visual melalui kegiatan melihat ekspresi dan gesture tokoh, indra audial dengan mendengarkan percakapan antartokoh binatang, dan kinestetik dengan menirukan aktivitas tokoh binatang dalam film.

Melalui proses pembelajaran seperti yang dideskripsikan di atas menunjukkan ditinjau dari posisi siswa, ada tiga gaya belajar siswa yang memungkinkan diakomodasi dengan menerapkan model VAK, yaitu gaya belajar visual, auditori, dan kinestetik. Ide utama tentang pembelajaran multimoda dan multimedia yang paling baik digambarkan oleh Mayer \& Moreno (2003). Mereka menjelaskan bahwa peserta didik lebih diuntungkan ketika belajar menggunakan kata-kata dan gambar daripada kata-kata saja. Dalam konteks ini, ia lebih lanjut menjelaskan bahwa kata dapat berupa teks tertulis dan lisan, dan gambar dapat berupa gambar, grafik, dan gambar bergerak. Selain itu, kesuksesan siswa di kelas dapat dikaitkan dengan teori Kazemi, Zafarghand \& Tahriri (2016) dari hasil penelitian mereka yang menyimpulkan bahwa dalam pembelajaran bahasa termasuk sastra, preferensi gaya merupakan faktor penting yang mendorong proses pembelajaran.

\section{SIMPULAN}

Melalui penelitian yang telah dilaksanakan, diketahui bahwa terdapat perbedaan yang signifikan pada kemampuan memerankan fabel peserta didik kelas eksperimen dengan peserta didik kelas kontrol. Kemampuan memerankan fabel kelas eksperimen dengan menerapkan model VAK melalui film animasi dinilai lebih tinggi dibandingkan dengan kemampuan memerankan fabel kelas kontrol. Hal ini menunjukkan bahwa model VAK melalui film animasi jauh lebih efektif dibandingkan dengan model konvensional dalam pembelajaran memerankan fabel.

\section{REFERENSI}

Brown, H. D. (2007). Teaching by Principles: an Integrative Approach to Language Pedagogy (3rd ed.). New York: Pearson Education, Inc. 
Emzir \& Rohman, S. (2016). Teori dan

Pengajaran Sastra. Jakarta: PT

Raja Grafindo Persada.

Handari, S. (2018). Efektivitas Teknik

Bermain Peran untuk

Meningkatkan Keterampilan

Sosial Anak Kota Samarinda

(Studi Kasus Melalui Pendekatan

Konseling Anak). HISBAH:

Jurnal Bimbingan Konseling dan

Dakwah Islam, 15 (2), 45-65

Joma, M.A.R., Al-Abed, S.F.M. \& Nafi, J.S.I. (2016). The Effect of "Role-playing" on Students' Achievement and Motivation in the Governmental Schools of Bethlehem District in Palestine. British Journal of Education, Society \& Behavioural Science, 18 (3), 1-25.

Kailani, A., Murcahyanto, H., \& Mariadah. (2020). Bentuk Pertunjukan Drama Tari Bejoraq, Jurnal Pendidikan Sejarah dan Riset Sosial Humaniora (KAGANGA), 3 (2), 62-69.

Kazemi, S., Zafarghand, A. \& Tahriri, A. (2016). The Relationship Between Learning Styles and Vocabulary Recall Among Sensorineural Hearing Loss EFL Learners. Journal of Applied Linguistics and Language Research, 3 (4), 325-346.

Mayer, R. E. \& Moreno, R. (2003). Nine Ways to Reduce Cognitive Load in Multimedia Learning. Educational Psychologist, 38, 43-52.
Learning in The Language

Classroom. Oxford: Oxford University Press.

Nurgiyantoro, B. (2010). Sastra Anak. Yogyakarta: Gadjah Mada University Press.

Rahmawati, L.S. \& Suseno. (2016). Pengembangan Buku Panduan Bermain Peran untuk Siswa SMP. Jurnal Pendidikan Bahasa dan Sastra Indonesia, 5 (2), 8-12.

Sapinahajar, Hsb. (2017). Penerapan Model Pembelajaran Bermain Peran dalam Pelajaran Bahasa Indonesia. Madah, 8 (2), 149160.

.Ramadian, O.D., Cahyono, B.Y. \& Suryati, N. (2019). The Implementation of Visual, Auditory, Kinesthetic (VAK) Learning Model in Improving Students' Achievement in Writing Descriptive Texts. English Language Teaching Educational Journal (ELTEJ), 2 (3), 142-149.

Rambe, H. H. \& Zainuddin. (2014). The Effect of Using Visual, Auditory, Kinesthetic (VAK) Learning Model on Students' Achievement in Writing Recount Text. REGISTER, 3 (4), 340-351.

Riener, C. \& Willingham, D. (2010). The Myth of Learning Style. Change: The Magazine of Higher Learning, 10, 32-35

Setyosari, P. (2012). Metode Penelitian dan Pengembangan. Jakarta: Prenada Media Group.

Hedge, T. (2000). Teaching and 
Suaib. R.H. (2017). The Use of Visual Auditory Kinesthetic (VAK) Learning Styles to Increase Students' Vocabulary. Didaktika Jurnal Kependidikan, 11 (2), 239-253

Swadayani, L.P.A., Sutama, I.M., \& Gunatama, G. (2018). Penerapan Metode Bermain Peran pada Pembelajaran Bahasa Indonesia Materi Fabel di Kelas VII 4 SMP Negeri 2 Singaraja. Jurnal Pendidikan Bahasa dan Sastra Indonesia, 8 (2), 322-331.

Wulansari, Y. (2016). The Use of

Visual Auditory Kinesthetic

(VAK) Learning Model to Improve Students' Reading Comprehension. Tesis Tidak Dipublikasi. FKIP IAIN Salatiga.

Zaini, H. (2008). Strategi Pembelajaran Aktif. Yogyakarta: Pustaka Insan Madani. 